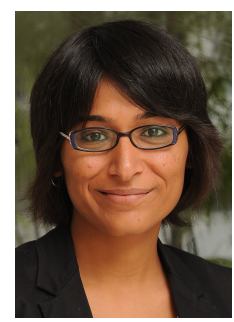

\title{
REDD+ AND THE CLEAN DEVELOPMENT MECHANISM: A COMPARATIVE PERSPECTIVE
}

Lovleen Bhullar

Assc Member, Asia-Pacific Centre for Environmental Law (APCEL)

National University of Singapore, and

Research Fellow, Environmental Law Research Society, New Delhi

The program, 'Reducing Emissions from Deforestation and Forest Degradation' (REDD), which operates within the international climate change policy framework, is projected to emerge as one of the key climate change mitigation mechanisms for developing countries. The existing Afforestation/Reforestation (A/R) mechanism, operating under the Clean Development Mechanism of the Kyoto Protocol to the United Nations Framework Convention on Climate Change, may prove useful for drawing lessons for the emerging REDD program, since both mechanisms represent flexible means for developed countries to achieve compliance with their mitigation targets under the Kyoto Protocol. The possible means include CDM as the basis for a project-based approach for the implementation of REDD (if adopted) or the inclusion of REDD within CDM. This article compares the features of $A / R$ $C D M$ and REDD, identifies similarities and differences, and analyses the extent to which the former can provide guidance for the development of a carbon governance mechanism for REDD. ${ }^{1}$

\section{Clean Development Mechanism: A background}

The United Nations Framework Convention on Climate Change 1994 ('UNFCCC') establishes the goal of 'stabilisation of greenhouse gas concentrations in the atmosphere at a level that would prevent dangerous anthropogenic interference with the climate system ...' . ${ }^{2}$ In order to achieve this goal, the Kyoto Protocol to the UNFCCC ('Kyoto Protocol' or 'Protocol') sets binding, quantified emission limitation and reduction commitments (QELRCs) for developed countries (Annex I Parties under the UNFCCC) to limit or reduce their greenhouse gas emissions. ${ }^{3}$ Three flexibility mechanisms have been established for this purpose: the Clean Development Mechanism, the Joint Implementation Mechanism and Emissions Trading. This article focuses on the first of these three mechanisms.

The Clean Development Mechanism (CDM), which is defined in Article 12 of the Kyoto Protocol, provides Annex I Parties with a cost-effective mechanism to meet a percentage of their QELRCs under the Protocol by implementing an emission reduction project in developing countries (Non-Annex I Parties). Such projects can earn saleable certified emission reduction (CER) credits, each equivalent to one tonne of $\mathrm{CO}_{2}$, which can be counted towards meeting a part of the country's QELRCs. All CDM projects are required to satisfy three requirements: (i) voluntary participation by the parties involved; (ii) real and measurable mitigation of emissions; and (iii) reductions that are additional to any that would have occurred in the absence of the project. ${ }^{4} \mathrm{CDM}$ is also supposed to assist host (developing) countries in achieving sustainable development by transferring new low carbon technologies and in contributing to the ultimate objective of the UNFCCC. ${ }^{5}$ The different types of CDM projects relate to renewable energy, transport, supply-side and demand-side energy efficiency, and afforestation and deforestation etc.

Articles 3(3) and 3(4) of UNFCCC establish the eligibility of different activities relating to the land-use, land-use change and forestry (LULUCF) sector under the Kyoto Protocol. But the inclusion of these activities

\footnotetext{
1 See also Alain Karsenty, 'The Architecture of Proposed REDD Schemes After Bali: Facing Critical Choices’ (2008) 10(3) International Forestry Review 443; Markus Lederer, 'From CDM to REDD+ - What Do We Know for Setting Up Effective and Legitimate Carbon Governance?’ (2011) 70 Ecological Economics 1900.

2 United Nations Framework Convention on Climate Change, opened for signature 9 May 1992 (entered into force 21 March 1994), art 2 ('UNFCCC').

3 Kyoto Protocol to the United Nations Framework Convention on Climate Change, opened for signature 10 December 1997 (entered into force 16 February 2005) ('Kyoto Protocol' or 'protocol').

Ibid art 12(5).

5 Ibid art 12(2).
} 
was not straightforward. In fact, the eligibility of LULUCF projects under CDM was one of the most controversial issues at the sixth session of the UNFCCC Conference of the Parties (COP-6) held at The Hague in November 2000. A compromise position was finally proposed: (1) designate avoided deforestation and combating land degradation and desertification in Non-Annex I Parties as adaptation activities eligible for funding through the Adaptation Fund but not through the sale of carbon credits; (2) allow only afforestation and reforestation projects in CDM, with measures to address non-permanence, social and environmental effects, leakage, additionality and uncertainty. ${ }^{6}$

The 2001 Marrakech Accords restricted the eligibility of LULUCF projects under CDM to afforestation and reforestation $(A / R)$ projects during the first commitment period (2008-2012). ${ }^{7}$ For the purpose of CDM A/R activities, the terms 'forest', 'afforestation' and 'reforestation' are defined as follows: ${ }^{8}$

\begin{abstract}
'Forest' is a minimum area of land of 0.05-1.0 hectare with tree crown cover (or equivalent stocking level) of more than 10-30 per cent with trees with the potential to reach a minimum height of 2-5 metres at maturity in situ. A forest may consist either of closed forest formations where trees of various storeys and undergrowth cover a high proportion of the ground or open forest. Young natural stands and all plantations which have yet to reach a crown density of 10-30 per cent or tree height of 2-5 metres are included under forest, as are areas normally forming part of the forest area which are temporarily unstocked as a result of human intervention such as harvesting or natural causes but which are expected to revert to forest.
\end{abstract}

'Afforestation' is the direct human-induced conversion of land that has not been forested for a period of at least 50 years to forested land through planting, seeding and/or the human-induced promotion of natural seed sources.

'Reforestation' is the direct human-induced conversion of non-forested land to forested land through planting, seeding and/or the human-induced promotion of natural seed sources, on land that was forested but that has been converted to non-forested land. For the first commitment period, reforestation activities will be limited to reforestation occurring on those lands that did not contain forest on 31 December 1989.

A cap is also set on an industrialised country's inclusion of CDM A/R CERs in its emissions accounting, that is one per cent of its base year emissions times five. ${ }^{9}$

Other forestry activities such as deforestation and avoided degradation are excluded from the Kyoto Protocol (and CDM). This was partly due to the sovereignty concerns of developing countries who refused to consider forests as a global public good, ${ }^{10}$ and who did not want to cede their control over land use decisions. The challenges and uncertainties inherent to quantifying forest sector emissions as well as methodological issues posed other major hurdles. ${ }^{11}$

There are a limited number of A/R CDM projects compared to other CDM projects. Of the more than 1000 CDM projects to date, only a few A/R project proposals have been submitted and approved/registered with the UNFCCC, including those listed in Table $1 .{ }^{12}$

${ }^{6}$ UNFCCC, Decision 5/CP.6, The Bonn Agreements on the Implementation of the Buenos Aires Plan of Action, UN Doc $\mathrm{FCCC} / \mathrm{CP} / 2001 / 5$ dated 25 September 2001.

7 UNFCCC, Decision 11/CP.1, Land Use, land-Use Change and Forestry, UN Doc FCCC/CP/ 2001/13/Add.1 dated 21 January 2002, Annex, paragraph 13

8 Ibid annex, para 1.

9 Ibid annex, para 14

${ }^{10}$ See Philip M Fearnside, 'Saving Tropical Forests as a Global Warming Countermeasure: An Issue that Divides the Environment Movement' (2001) 39(2) Ecological Economics 167; William F Laurance, 'A New Initiative to Use Carbon Trading for Tropical Forest Conservation' (2007) 39(1) Biotropica 20; Stephanie Engel and Charles Palmer, 'Painting the Forest REDD? Prospects for Mitigating Climate Change through Reducing Emissions from Deforestation and Degradation' (IED Working Paper 3, 2008) <http://e-collection.library.ethz.ch/eserv.php?pid=eth:41892\&dsID=eth-41892-01.pdf>.

${ }^{11}$ Fearnside, above $\mathrm{n} 10$; Laurance, above $\mathrm{n} 10$.

${ }^{12}$ This table is based on Sebastian Thomas et al, 'Why Are There So Few Afforestation and Reforestation Clean Development Mechanism projects? (2010) 27 Land Use Policy 880; EuropeAid, 'Afforestation Clean Development Project in Northern India - Haryana Community Forestry Project' <http://ec.europa.eu/europeaid/documents/casestudies/india_forestry haryana_en.pdf>; 'Himachal Pradesh Becomes First Indian State to Sell Carbon Credits to the World Bank', Daily News and Analysis, 23 May 2011 <http://infochangeindia.org/environment/news/himachal-pradeshbecomes-first-indian-state-to-sell-carbon-credits-to-the-world-bank.html>. 
Table 1: A/R project proposals submitted and approved/registered with the UNFCCC

\begin{tabular}{|c|c|c|c|c|c|c|c|}
\hline $\begin{array}{l}\text { S. } \\
\text { No. }\end{array}$ & Country & Name of Project & Area (in ha) & $\begin{array}{l}\text { Project } \\
\text { start }\end{array}$ & $\begin{array}{l}\text { Credit } \\
\text { period }\end{array}$ & Renewals & $\begin{array}{c}\text { Type of A/R } \\
\text { activity }\end{array}$ \\
\hline 1 & China & $\begin{array}{l}\text { Guangxi Watershed } \\
\text { Project }\end{array}$ & 4000 & 1 April 2006 & 30 & None & $\begin{array}{l}\text { Restoration of } \\
\text { natural forest } \\
\text { \& plantation }\end{array}$ \\
\hline 2 & Moldova & $\begin{array}{l}\text { Moldova Soil Con- } \\
\text { servation Project }\end{array}$ & 20289 & $\begin{array}{c}1 \text { October } \\
2002\end{array}$ & 20 & $\begin{array}{c}2 * 20+40 \\
\text { operational }\end{array}$ & $\begin{array}{l}\text { Restoration of } \\
\text { degraded land }\end{array}$ \\
\hline 3 & India & $\begin{array}{l}\text { Cooperative A/f } \\
\text { Haryana Project }\end{array}$ & 370 & 1 July 2008 & 20 & $2 * 20$ & $\begin{array}{l}\text { Restoration of } \\
\text { cropland }\end{array}$ \\
\hline 4 & Vietnam & Cao Phong Project & 385 & 1 May 2009 & 16 & At least one & $\begin{array}{l}\text { Reforestation } \\
\text { of cropland } \\
\text { and grassland }\end{array}$ \\
\hline 5 & India & $\begin{array}{l}\text { Andhra Pradesh } \\
\text { Reforestation } \\
\text { Project }\end{array}$ & 3070 & 2 July 2001 & 30 & None & $\begin{array}{l}\text { Reforestation } \\
\text { of degraded } \\
\text { land }\end{array}$ \\
\hline 6 & Bolivia & CETEFOR Project & 247 & $\begin{array}{l}12 \text { February } \\
2008\end{array}$ & 21 & None & $\begin{array}{l}\text { Reforestation } \\
\text { of cropland } \\
\text { and grassland }\end{array}$ \\
\hline 7 & India & $\begin{array}{l}\text { Mid-Himalayan } \\
\text { Watershed Devel- } \\
\text { opment Project }\end{array}$ & 4003.07 & 2006 & 20 & $\begin{array}{l}\text { One }(40 \\
\text { years })\end{array}$ & $\begin{array}{l}\text { Restoration of } \\
\text { watershed }\end{array}$ \\
\hline
\end{tabular}

The A/R CDM projects listed in Table 1 are on private or communal lands. They are usually developed by international NGOs or state agencies who can provide technical expertise for project design and implementation. Because of the large investment requirement, they are funded by non-profit NGOs, state agencies or private investors. $^{13}$

There are several reasons for the limited number of A/R CDM projects. These include the limited scope of such projects (restricted to A/R activities), high transaction costs due to complex rules and methodologies, registration costs, issues related to measurement and monitoring, and lack of transferability of the temporary credits assigned to projects etc. ${ }^{14}$ The calculation of real emissions removals presents a major problem due to issues concerning permanence, additionality and leakage; these three terms are briefly discussed below.

A/R CDM projects create a new sink that grows and absorbs atmospheric carbon, but it will cease to absorb carbon at some point in time. ${ }^{15}$ The achieved sequestration may also be reversed, in which case the reduction of carbon in the atmosphere is nullified. ${ }^{16}$ In order to address the non-permanence issue, temporary credits or tCERs (which expire at the end of the commitment period) or long-term expiring credits or ICERS (which are valid for the crediting period) are issued for A/R projects. Their price value is only a fraction of the value of 'permanent credits' and they have to be renewed or replaced when they expire. ${ }^{17}$ Karsenty identifies several reasons for the reluctance of private operators to buy such credits, including the availability of a number of permanent credits at a moderate price on the CDM market. ${ }^{18}$ The decision of the European Union (EU) to exclude A/R CDM credits from the EU Emissions Trading Scheme (ETS) also imposed a considerable constraint in market opportunities for mitigation activities from the forestry sector in developing countries. ${ }^{19}$

\footnotetext{
13 Thomas, above n 12 .

${ }^{14}$ See Arild Angelsen et al, 'What is the Right Scale for REDD? The Implications of National, Subnational and Nested Approaches' (InfoBrief No. 15, Centre for International Forestry Research, 2008) 2; Thomas, above n 12.

${ }^{15}$ Margaret Skutsch and Eveline Trines, 'Understanding Permanence in REDD' (Policy Paper No 6, The Kyoto Think Global Act Local Project (K:TGAL), 2010) <http://www.communitycarbonforestry.org/NewPublications/KTGAL\%20Policy\% 20Note\%206\%20Permanance\%20in\%20REDD.pdf>. See also Michael Dutschke and Arild Angelsen, 'How Do We Ensure Permanence and Assign Liability?' in Arild Angelsen (ed), Moving Ahead with REDD: Issues, Options and Implications (CIFOR, 2008); Margaret Skutsch and Ben de Jong, 'The Permanence Debate' (2010) 327 Science 107.

${ }^{16}$ Skutsch and Trines, above n 15.

${ }^{17}$ Karsenty, above n 1, 445.

18 Ibid.

19 Pham Manh Cuong, ‘REDD, LULUCF and CDM - Recent International Developments' (2010)

<http://www.iges.or.jp/en/fc/pdf/activity_201003/Vietnam/08_Cuong_REDD_Negotiation_processes.pdf>.
} 
The additionality of an A/R CDM project can be assessed by comparing its activities with a reference scenario ${ }^{20}$ consisting of the course of host country activities (which needs to be defined) that would occur without the project. ${ }^{21}$ Various authors have shown that a certain percentage of CDM projects are simply not additional. ${ }^{22}$ Decision 19/CP.9 defines leakage as the increase in greenhouse gas emissions by sources, which occurs outside the boundary of A/R CDM project activity, and which is measurable and attributable to the A/R project activity. ${ }^{23}$ Leakage is inevitable given the project-based approach adopted by CDM projects. These three concerns (impermanence, additionality and leakage) have seriously undermined the effectiveness of A/R CDM projects.

\section{REDD+ and CDM: The way forward?}

Like CDM, Reducing Emissions from Deforestation and Degradation (REDD) is a carbon mitigation mechanism within the UNFCCC framework. In recent years, the idea has evolved from REDD in the Bali Action Plan, ${ }^{24}$ to REDD Plus (or REDD+). REDD+ is REDD with conservation and enhancement of forest carbon stocks, and sustainable management of forests added.

Given the purported success of CDM in meeting the carbon mitigation commitments of developed countries through activities undertaken in developing countries, comparisons between CDM and REDD+ were inevitable. It is argued that CDM experiences can facilitate the future development of REDD+. The inclusion of REDD+ in the CDM framework has also been proposed. For example, a report of the High-Level Panel on the CDM Policy Dialogue (September 2012) highlights the potential benefits of including REDD+ activities in CDM as follows:

[P]romoting sustainable development; shifting the distribution of CERs towards a more equitable balance among countries (as several forested developing countries do not have many opportunities in other sectors); creating further options for generating cost-effective reductions; and facilitating learning-by-doing for how to include REDD+ in carbon markets'. ${ }^{25}$

According to the report, the inclusion of REDD+ in the CDM could also 'create a stable, low-cost source of future CERs'. ${ }^{26}$ Although the report does not dismiss the potential risks of including REDD+ activities in $\mathrm{CDM},{ }^{27}$ most of which have been discussed above, it suggests 'careful design' as the method to mitigate many of these risks. ${ }^{28}$ According to the report, the inclusion of 'limited project-based REDD+ and/or largerscale (sub-national or national) pilot activities into the CDM' can 'create important learning-by-doing opportunities for the international community in anticipation of future REDD+ mechanisms, which may accelerate their development'. ${ }^{29}$ It further states that the inclusion of REDD+ in CDM 'would also help direct CDM projects and programmes toward nations that might not otherwise participate in the sustainable development benefits of the CDM and might not otherwise gain experience with carbon markets'. ${ }^{30}$ The report then suggests that ' $[1]$ nstead of taking up all activities within the scope of REDD+, development of those activities already covered by the CDM in afforestation and reforestation should be pursued further'. ${ }^{31}$

On the other hand, concerns have also been raised about the trend drawing parallels between CDM and REDD+. Table 2 shows the differences between these two carbon mitigation mechanisms.

${ }^{20}$ The reference scenario is a counterfactual hypothesis representing the 'best guess' regarding the future course of events. See Karsenty, above n 1, 444.

${ }^{21}$ Ibid.

${ }^{22}$ See, for eg, Alex Michaelowa and Pallav Purohit, 'Additionality Determination of Indian Projects: Can Indian CDM Project Developers Outwit the CDM Executive Board?’ (2007) <http://medias.lemonde.fr/mmpub/edt/doc/20070608/ 920594_additionality_determination_of_indian_cdm_projects.pdf $>$.

${ }^{23}$ UNFCCC, Decision 19/CP 9, Modalities and Procedures for Afforestation and Reforestation Project Activities Under the Clean Development Mechanism, UN Doc. FCCC/CP/2003/6/Add 2 dated 30 March 2004, annex.

24 The Bali Action Plan called for "policy approaches and positive incentives on issues relating to reducing emissions from deforestation and forest degradation in developing countries; and the role of conservation, sustainable management of forests and enhancement of forest carbon stocks in developing countries', see UNFCCC, Conference of the Parties Thirteenth Session, Dec. 3-15, 2007, Report of the Conference of the Parties on its Thirteenth Session, I 1, UN Doc FCCC/CP/2007/6/Add.1, 1/1/CP.13 dated 14 March 2008, para 1(b)(iii) ('Bali Action Plan').

${ }^{25}$ CDM Policy Dialogue, 'Climate Change, Carbon Markets and the CDM: A Call to Action' (Report of the High-Level Panel on the CDM Policy Dialogue, September 2012) 28-29 <http://www.cdmpolicydialogue.org/report/rpt110912.pdf>.

${ }^{26}$ Ibid 29-30.

27 Ibid 28-29.

${ }^{28}$ Ibid 29-30.

29 Ibid 28

${ }^{30}$ Ibid 29.

31 Ibid 30. 
Table 2: Difference between CDM and REDD+

\begin{tabular}{|c|c|c|}
\hline & CDM & REDD+ \\
\hline Activities & $\begin{array}{ll}\text { - } & \text { Reducing emissions from afforestation } \\
\text { - } & \text { Reducing emissions from reforestation }\end{array}$ & $\begin{array}{ll}\text { - } & \text { Reducing emissions from deforestation } \\
\text { - } & \text { Reducing emissions from forest degradation } \\
\text { - } & \text { Conservation of forest carbon stocks } \\
\text { - } & \text { Sustainable management of forests } \\
\text { - } & \text { Enhancement of forest carbon stocks } \\
\end{array}$ \\
\hline Coverage & $\begin{array}{l}\text { Uneven distribution in favor of emerging } \\
\text { economies (China, India, Brazil); bypasses } \\
\text { least developed countries (for example, in } \\
\text { Africa) }\end{array}$ & $\begin{array}{l}\text { Focus on least developed countries in the tropics } \\
\text { (for example, Democratic Republic of Congo and } \\
\text { Laos) }\end{array}$ \\
\hline Scale & Project-based & National, sub-national or hybrid \\
\hline $\begin{array}{l}\text { Compliance \& } \\
\text { Liability }\end{array}$ & Low host country involvement & Higher host country involvement \\
\hline
\end{tabular}

Some of the issues confronting A/R CDM projects and REDD+ activities appear to be similar, for example permanence, additionality and leakage, and it may be argued that they can be resolved in a similar manner. Critics will, of course, point to the fact that some aspects of these issues have not been (and cannot be) fully resolved. Further, a number of other outstanding issues need to be discussed before determining the extent to which A/R CDM projects can provide the basis for operationalising REDD+. This section highlights some of these issues.

\section{Definitional concerns}

The term 'forest' needs to be defined for the purpose of REDD+ given the fundamental difference between the scope of forestry activities under CDM and REDD+. The other terms that require definition include 'sustainable management of forests' and 'enhancement of carbon stocks', which form the building blocks of any REDD+ framework. ${ }^{32}$ Given the differences in the nature of forests in different countries, these definitions are more likely to evolve at the national level rather than at the international level, as was the case for CDM. Further, the interactions between REDD+ activities and the drivers of deforestation such as agricultural expansion, wood extraction and infrastructure extension must be taken into account.

\section{Scalar issues ${ }^{33}$}

There is considerable difference of opinion about the right scale for REDD+ activities. The three commonly discussed possibilities are:

(i) At the national level, where direct support is given to national governments of developing countries and the whole forest area of the host countries is covered.

a. Advantages: allows pursuit of a broad set of policies, addresses domestic leakage, and creates country ownership.

b. Challenges: only feasible for a few countries (in short- to medium-term), does not work well in situations susceptible to governance failures, and less likely to mobilise private sector investment and local government involvement.

(ii) A subnational/project approach, where international/external financing is based on individual projects. This is similar to CDM.

a. Advantages: early involvement, wide participation and attractive to private investors.

b. Challenges: leakages, failure to address broader forces driving deforestation and forest degradation.

(iii) A hybrid/nested approach. ${ }^{34}$

a. Advantages: most flexible mechanism.

b. Challenges: harmonisation.

The limited success of $A / R$ projects suggests that a project-based REDD approach cannot simply replicate the CDM model. ${ }^{35}$ As argued by Skutsch and Trines, while it may be possible to use the project-based REDD

\footnotetext{
${ }^{32}$ See, eg, Nophea Sasaki and Francis E Putz, 'Do Definitions of Forest and Forest Degradation Matter in the REDD Agreement?’ (Working Paper, 5 December 2008) <http://dx.doi.org/10.2139/ssrn.1306431>.

33 This section draws on Angelsen, above $\mathrm{n} 14$

${ }^{34}$ See also Lucio Pedroni et al, 'Creating incentives for avoiding further deforestation: the nested approach' (2009) 9(2) Climate Policy 207.
} 
model for pilot purposes in the interim, it is unlikely to survive when national REDD programmes get fully operational because most governments prefer to keep the REDD programme in their own hands rather than allowing projects to be individually funded and from outside. ${ }^{36}$

\section{Leakage}

Leakage refers to the shifting of deforestation from the site where REDD+ activities are being undertaken to another location. ${ }^{37}$ According to Madeira, this may take place directly, where deforestation agents shift their equipment and labour to a nearby patch of forest, or indirectly where the market price of timber, livestock and crops increases as a result of REDD activities. ${ }^{38}$ She recommends the buffer approach to minimise leakage where 'leakage can be accounted for by requiring that a percentage of a project's REDD credits be held in reserve and not be sold. In this manner, the reserve account would offset or neutralise the leakage that was assumed to have taken place. ${ }^{39}$

\section{Additionality}

It is more difficult to assess additionality (that is, what would have occurred in terms of deforestation without REDD+) at the national level than at the project level (as in the case of A/R CDM projects) because of the co-existence of a much larger number of variables, including the man-made and natural causes of deforestation. ${ }^{40}$ Ongoing pilot/demonstration REDD activities have also been criticised for their failure to satisfy the additionality criterion. For example, it has been argued that the Meghalaya REDD pilot project does not meet the additionality requirement because the local communities were undertaking carbon mitigation activities anyway although they were not known by this name. ${ }^{41}$ The additionality requirement may also deprive countries that have already taken actions to prevent deforestation from REDD+ incentives. It has been argued that countries with low rates of deforestation should be rewarded (outside the REDD+ mechanism) to avoid creating perverse incentive for these countries to increase deforestation in order to then qualify for REDD incentives. ${ }^{42}$

\section{Baselines}

In order to assess the effectiveness of a REDD+ activity and the allocation of emissions reduction credits, it is necessary to determine the 'baseline' or 'a level of emissions that would occur in the absence of a forest carbon policy and is used as a reference case for quantifying mitigation performance'. ${ }^{43}$ Different methods are available in order to determine the baseline including the 'national circumstances' approach and calculating historical (national/global) deforestation rates based on existing remote sensing imagery. However, many regions and countries argue that historic rates do not indicate the current risk of deforestation. One example is countries that have a low rate of deforestation because they are experiencing political instability, which limits access to forests and markets. But an improvement in the political situation may result in an increase in deforestation, in which case historic baseline underestimates the real pressure on the forests. $^{44}$

\section{Permanence}

It is hard to ensure the permanence of any carbon storage/emission reductions achieved as a result of REDD+ activities. ${ }^{45}$ Impermanence refers to their potential reversibility due to the vulnerability of forests to

\footnotetext{
${ }^{35}$ Angelsen, above n 14, 3.

${ }^{36}$ Skutsch and Trines, above $\mathrm{n} 15$.

37 See Sven Wunder, 'How do we deal with leakage' in Arild Angelsen (ed), Moving Ahead with REDD: Issues, Options and Implications (CIFOR, 2008) 65-75.

${ }^{38}$ See Erin C Myers Madeira, 'Policies to Reduce Emissions from Deforestation and Degradation (REDD) in Developing Countries - An examination of the issues facing the incorporation of REDD into market-based climate policies' (Resources for the Future, 2008) 11.

39 Ibid 10-11.

${ }^{40}$ Karsenty, above n 1, 445

${ }^{41}$ Chris Lang, 'India's First REDD Project in the East Khasi Hills: “When You Say That I Need Permission to Cut My Own Tree, I Have Lost My Right to My Land!”' (29 November 2011) <http://www.redd-monitor.org/2011/11/29/indias-firstredd-project-in-the-east-khasi-hills-when-you-say-that-i-need-permission-to-cut-my-own-tree-i-have-lost-my-right-tomy-land/>.

${ }^{42}$ Erin C Myers, 'Climate Change and Forestry: A REDD Primer' (2011) <http://www.katoombagroup.org/documents/cds/ uganda_2011/REDD/Climate\%20Change\%20and\%20Forestry \%20A\%20REDD\%20Primer.pdf>.

${ }^{43}$ Lydia P Olander et al, 'International Forest Carbon and the Climate Change Challenge: Issues and Options' (Nicholas Institute Policy Brief, Duke University, 2009) 32.

${ }^{44}$ Myers, above $\mathrm{n} 42$.

${ }^{45}$ Dutschke and Angelsen, above n 15; Bernhard Schlamadinger and Penny Baalman, 'Scaling Up AFOLU Mitigation Activities in Non-Annex I Countries’ (Report Commissioned for the Eliasch Review, Climate Strategies, 2008).
} 
natural and anthropogenic disturbances. ${ }^{46}$ The non-permanence issue in REDD+ can be resolved by discounting the carbon stored in trees, thereby taking into account that some of it might be lost; ${ }^{47}$ or putting some carbon profits into an insurance fund to compensate for non-permanence. ${ }^{48}$ The scale at which REDD+ activities are implemented also influences the risk of non-permanence. For example, there is no requirement to maintain forest carbon in any one specific location as one moves from project-scale to sectoral-scale activities, and increases in deforestation in one place can be offset with reducing deforestation at another location. ${ }^{49}$

\section{Use of market-based instruments}

REDD+ activities in developing countries would at least partially be eligible for offsets in developed countries. Proponents of market-based instruments argue that markets provide incentives and generate enough resources to actually stop deforestation. But there is great opposition to the use of market-based instruments in the context of REDD+ compared with CDM. According to the opponents, however, if REDD+ credits were fungible and could be traded, the amount of supply generated would eventually flood the regulatory market with cheap credits. ${ }^{50}$ This would deflate CER prices, endanger the credibility of the CDM market and remove the incentives for developed countries to generate domestic reduction credits, ${ }^{51}$ or develop lowcarbon technologies such as carbon capture and storage. According to Lederer (2011), however, this seems exaggerated because the generation of such credits is subject to the implementation of REDD+ projects by developing countries, which will first require considerable capacity development. ${ }^{52}$ As a result, at present, the credits generated from REDD activities can only be traded on voluntary markets, such as the Chicago Climate Exchange, or paid for using designated carbon funds, such as the World Bank's Forest Carbon Partnership Facility (FCPF).

\section{Rights of indigenous communities}

REDD+ exerts stronger influence on local governance issues than CDM. Unlike A/R CDM projects, which are mostly developed on private lands, the focus of REDD+ is government-owned forests in developing countries where security of tenure and unclear and contested land ownership rights is a major issue. As a result, REDD + activities have a far greater potential to harm local communities and indigenous groups if not implemented with appropriate safeguards. ${ }^{53}$ The implementation of REDD+ activities is dependent upon answers to questions such as: Who owns forest carbon? Who gets compensated? How much each stakeholder should receive? Will the benefits reach the communities bearing the burden of forest stewardship? How will the priorities of forest-dependent communities and indigenous peoples be satisfied? The answers to these questions are difficult in the absence of clear and legally defined ownership structures.

The conflict can be illustrated by considering the situation in India where the Government of India has enacted the Scheduled Tribes and Other Traditional Forest Dwellers (Recognition of Forest Rights) Act 2006 to recognise the rights of these historically marginalised forest-dependent communities. At the same time, the government has actively endorsed and is promoting REDD+ as a carbon mitigation mechanism. This is a very contentious issue and there is widespread concern that the interests of forest-dependent communities may be subsumed in order to grab land to accommodate the large private players who would be interested in REDD+ activities once they are successfully operationalised.

Further, unlike CDM, REDD+ requires much more input-oriented legitimacy given that the participation of indigenous peoples and local communities is imperative in several cases. This, in turn, may lead to stronger trade-offs with effectiveness of REDD+ as co-benefits, namely poverty alleviation, carbon mitigation and stemming biodiversity loss may not materialize easily. ${ }^{54}$ REDD+ also has to address issues relating to forestry sector governance. These include built-in perverse incentives for corruption in emissions offsets programs

\footnotetext{
${ }^{46}$ Madeira, above n 38, 12.

${ }^{47}$ Ian Fry, 'Reducing emissions from deforestation and forest degradation: opportunities and pitfalls in developing a new legal regime' (2008) 17 Review of European Community \& International Environmental Law 166.

${ }^{48}$ Charlotte Streck, 'Financing REDD: A Review of Selected Policy Proposals' (Climate Focus, 2009).

${ }^{49}$ Myers, above $\mathrm{n} 42$.

${ }^{50}$ Paul Leach, 'Carbon Sunk? The Potential Impacts of Avoided Deforestation Credits on Emissions Trading Mechanisms' (Rainforest Foundation UK, 2008).

${ }^{51}$ K Karaousakis, 'Incentives to Reduce GHG Emissions from Deforestation: Lessons Learned from Costa Rica and Mexico' (OECD, 2007).

${ }^{52}$ Lederer, above n 1, 1902.

${ }^{53}$ See, eg, Tom Griffiths, 'Seeing ‘REDD’?: Forests, climate change mitigation and the rights of indigenous peoples and local communities’ (Forest Peoples Programme, 2008).

54 Lederer, above n 1, 1905.
} 
setting baseline levels, reconciling project and national credits in nested model, and long-term monitoring and enforcement. ${ }^{55}$

\section{Validation procedure/criteria and sustainable development}

Similar to CDM, countries may be required to develop procedures and criteria for validating REDD+ projects. Article 12 of the Kyoto Protocol stipulates that CDM projects must contribute to sustainable development in host countries. Host countries are responsible for defining sustainable development criteria and ensuring that projects adhere to these criteria as a condition for CDM project registration. Therefore, countries have to define a procedure for project approval. Most countries developed simple checklists often consisting of social, environmental and economic benefits. The lack of a common standard or benchmark for sustainable development criteria has led to an inadequate consideration of sustainable development in CDM projects. ${ }^{56}$ The legitimacy of REDD+ activities will depend considerably on the ability of national governments to determine validation procedures/criteria.

\section{Conclusion}

Forests form the core of A/R CDM projects and REDD+ activities, and some of the issues incorporated by the two frameworks are common, such as leakage, additionality, permanence and baselines. However, the potentially multi-scalar nature of REDD + activities is likely to raise a number of additional issues. The limited scope of $A / R$ CDM projects precluded concerns relating to governance of forests in developing countries but forest governance reform is critical for the success of REDD+ activities. Further, protection of rights of indigenous communities and sustainability of forest use must form an integral part of REDD+ activities unlike A/R CDM projects, which have largely failed to fulfil their goals of promoting sustainable development in developing countries while generating CER credits for developed countries.

The lessons learnt from operationalising A/R CDM projects - for example the reasons for the limited marketability of credits generated - are useful to keep in mind when considering the appropriate financial mechanism for REDD+ activities, but the existing CDM framework cannot form the basis for REDD+ activities in the future. Nor is it possible to automatically include REDD+ activities in the CDM framework. It is also important to remember that while consensus has been generated in some quarters regarding the potential of REDD+, the resolution of a number of outstanding issues is a pre-requisite before the implementation of REDD+ activities as a part of the international climate change mitigation framework.

\footnotetext{
${ }^{55}$ Michael L Brown, 'Limiting Corrupt Incentives in a Global REDD Regime' (2010) 37 Ecology Law Quarterly 237.

${ }^{56}$ Peter A Minang and Deborah Murphy, 'REDD after Copenhagen: The way forward' (ASB IISD, 2010)

<http://www.iisd.org/pdf/2010/redd_after_copenhagen.pdf>.
} 